Maurer School of Law: Indiana University

Digital Repository @ Maurer Law

1931

\title{
Restrictions on State Taxation Because of Interference with Federal Functions
}

Robert C. Brown

Indiana University School of Law

Follow this and additional works at: https://www.repository.law.indiana.edu/facpub

Part of the Taxation-Federal Commons, and the Taxation-State and Local Commons

\section{Recommended Citation}

Brown, Robert C., "Restrictions on State Taxation Because of Interference with Federal Functions" (1931). Articles by Maurer Faculty. 1743.

https://www.repository.law.indiana.edu/facpub/1743

This Article is brought to you for free and open access by the Faculty Scholarship at Digital Repository @ Maurer Law. It has been accepted for inclusion in Articles by Maurer Faculty by an authorized administrator of Digital Repository @ Maurer Law. For more information, please contact rvaughan@indiana.edu. 


\section{RESTRICTIONS ON STATE TAXATION BECAUSE OF INTERFERENCE WITH FEDERAL FUNCTIONS}

$\mathrm{T}$

HERE is probably no more perplexing problem in American constitutional law than the mutual relation between the states and the national government. With our dual form of government, and the consequent operation within the same territory and often upon the same subject matter, of two separate and largely independent governmental systems, the problem of adjustment between them has been one of great difficulty and one which will perhaps never be fully settled. In this matter, as in many others, the ultimate authority, the Supreme Court of the United States, has not been able to do more than to determine the point of boundary in specific cases, without attempting to draw a line which will determine on which side any possible case will fall.

Of this perplexing problem one of the most difficult phases is that of taxation. It is often laid down in general terms that neither government may levy a tax which will interfere with the functions of the other, but this obviously means nothing until the Supreme Court has determined the situations in which such interference exists or does not exist. Recent decisions of that Court have to some extent clarified the situation, but the matter still presents many difficulties. It is the purpose of this paper to consider the present views of the Court as to what taxation by a state will be considered invalid as interfering with federal governmental functions.

\section{The General Problem}

The question here presented is, as already said, a very perplexing one. Furthermore, it may involve a restriction upon the federal government as well as upon the states, since the latter are as immune from federal interference with their functions as is the federal government from state interference. The general problem has been presented to the Supreme Court many times and in several different aspects. It would no doubt be difficult to recon- 
cile all the deliverances of the Court with reference to this question. But it is important to notice that this matter of the adjustment of state taxation with respect to federal powers and functions has come before the Court in two entirely different kinds of cases, as to which the rules are not the same.

The first of these is state taxation which may affect interstate or foreign commerce or commerce with the Indians (hereafter referred to collectively as "interstate commerce"). The Constitution gives the federal government power to regulate such commerce-which is certainly no proof that the states may not also have a subordinate power of regulation. ${ }^{1}$ But however this may be, it is clear that the states may not, by taxation or otherwise, discriminate against such commerce, and their power of taxation is even further limited with respect to it, as will hereafter appear. ${ }^{2}$

The other aspect of this matter, and the one more particularly under consideration here, is the situation which arises where a state or national tax is claimed to interfere with the actual functions of the other government-as by taxing salaries or interest received from the other government. There is no specific constitutional provision against this sort of taxation, but it is clearly settled that it is forbidden to both sides. This seems manifestly correct, since unlimited power of either jurisdiction to tax the functions of the other would not be tolerable, as it would enable the states to stop the functioning of the federal government, or vice versa. $^{3}$ Indeed, the Court is justified in making the test here somewhat stricter than in the other cases of possible interference, and it seems in fact to have done so. The reason for the greater strictness in this class of cases is that, while the states have in

${ }^{2}$ In certain instances, state regulation of interstate commerce has in fact been sustained. See, as examples of this, Cooley v. Board of Wardens, 12 How. 299 (U. S. 1851) ; Willson v. Black Bird Creek Marsh Co., 2 Pet. 245 (U. S. 1829):

* A very similar question arises with respect to taxes upon imports and exports. This is perhaps not strictly a question of the boundaries between federal and state taxation, since the states can tax neither exports nor imports, while the federal government is forbidden to tax only exports. But the same question as to how far a purely incidental and non-discriminatory burden is forbidden appears here also. For the present purpose the test may be regarded as the same as in the interstate commerce cases; and cases of this sort will be referred to as in point in connection with the taxation of interstate commerce.

${ }^{3} M^{\circ}$ Culloch v. Maryland, 4 Wheat. 316 (U. S. 1819). 
theory no power to burden interstate commerce, yet they do have the right to tax the property of corporations engaged in such commerce. $^{4}$ The line between property taxation and an improper burden upon interstate commerce is often a close one, but at any rate the test is much more liberal than where the state has no power whatever to tax the property or function, as is the situation in the cases in this latter category.

\section{The Interstate Commerce Cases}

The general rule laid down with respect to the power of the states to levy taxes affecting interstate commerce is that no tax may be levied which interferes with such commerce. This rule is obviously too vague to be helpful; and it is hardly more helpful to say, as is sometimes done, that the commerce may not be taxed. but that property used for carrying on interstate commerce and found within the state is subject to state taxation." The problem of drawing the line between the permitted and the prohibited state taxation still remains to be solved.

One fairly definite rule may be laid down: that is that the states will not be permitted to discriminate against interstate commerce. ${ }^{6}$ The rule is applied with great strictness, so that the most trifling discrimination will generally suffice to upset a state tax. On the other hand, it seems that many cases where a state tax has been upset on the broad ground that it regulated interstate commerce can actually be explained as involving discrimination. $^{7}$ There are, to be sure, cases which seem to permit taxation

- Pullman's Palace Car Co. v. Pennsylvania, 141 U. S. 18 (1891). But the states may not tax the commerce itself. Case of the State Freight Tax, 15 Wall. 232 (U. S. 1872).

'See Galveston, etc., Ry. v. Texas, 210 U. S. 217 (1908).

' Cook v. Pennsylvania, 97 U. S. 566 (1878); Welton v. Missouri, 91 U. S. 275 (1875).

The leading case of Brown v. Maryland, 12 Wheat. 419 (U. S. 1827), and the case of Almy v. California, 24 How. 169 (U. S. 1860), in both of which the Court laid down in broad terms the doctrine that the states have no power to tax interstate commerce, are explained by the later case of Woodruff v. Parham, 8 Wall. 123 (U. S. 1868), as depending upon the same principle, namely, that the states may not impose discriminatory taxation upon interstate commerce. In both of the earlier cases the invalidated tax was undoubtedly discriminatory, but the Court did not apparently notice this, and in the Brown case there is a rather curious dictum by Chief Justice Marshall that the opinion has no reference to a discriminatory tax. 
which in fact discriminates against interstate commerce ${ }^{8}$ but in these cases the tax was regarded as only a proper method of carrying out the acknowledged powers of the state, and indeed the Supreme Court did not very clearly recognize the existence of discrimination. It is probable that the Court has never corsciously permitted such discrimination.

On the other hand, the Court has until comparatively recently adhered to the position that the power of the states over corporations was plenary." It followed that a state could impose such franchise taxes as it chose upon domestic corporations; and could likewise impose any tax it chose upon foreign corporations admitted to do business in the state, upon the theory that this was a license tax for the privilege of being admitted to the state. It is not difficult to see that by imposing such taxes a state may substantially burden interstate commerce. If a domestic corporation is engaged in interstate commerce, that commerce is burdened by a heavy franchise tax imposed upon the corporation. The burden is not so clear in the case of a foreign corporation, since a foreign corporation which carries on no activities within the state except in connection with interstate commerce need not secure permission to do business in the state, and so is not liable to a state license tax. ${ }^{10}$ Nevertheless it happens frequently that a foreign corporation does both interstate and local business, and because of its local business must become qualified to do business in the state. In such a case it is clear that a license tax upon the corporation may in fact burden interstate commerce.

It follows that the theory of the plenary power of states over domestic and foreign corporations is logically inconsistent with the assumption that the states may not burden interstate commerce. An actual impact between this irresistible force of state rights over its own corporations, or those foreign corporations which it has admitted to do business, and the immovable body of lack of power to burden interstate commerce, has thus been inevitable.

Of late years the Court has been seeking a way out of this diffi-

" Armour \& Co. v. Virginia, 246 U. S. 1 (1918); Reymann Brewing Co. v. Brister, 179 U. S. 445 (1900).

- See Paul v. Virginia, 8 Wall. 168 (U. S. 1868).

${ }^{10}$ Alpha Portland Cement Co. v. Massachusetts, 268 U. S. 203 (1925). 
culty by developing the theory that "unconstitutional conditions" cannot be imposed by the states, even for the granting of a privilege within their control. ${ }^{11}$ That an improper tax burden upon a corporation engaged in interstate commerce may constitute such an unconstitutional condition, which the states are forbidden to impose, is shown by Western Union Telegraph Co. v. Kansas. ${ }^{12}$ Here a foreign corporation engaged in transmitting telegrams both intrastate and interstate, was assessed a state tax measured by its entire authorized capital stock, a comparatively small proportion of which was represented by property within the taxing state. By reason of the failure of the corporation to pay this tax, a decree was secured from the state court ousting it from local business, though not from interstate commerce. This decree was reversed by the Supreme Court of the United States, which held that the tax was an undue burden upon both interstate and intrastate commerce, and that the company could not be denied the right to carry on intrastate commerce without thereby improperly burdening the interstate business. Accordingly, the state was compelled to permit the company to continue both its interstate and its local business.

Nevertheless, the Court still sustains in some instances state taxation upon foreign corporations based upon their issued capital

\footnotetext{
is An interesting example of this doctrine of unconstitutional conditions in another field is in connection with the efforts of the states to compel foreign corporations to agree, as a condition of their being permitted to do business in the state, not to remove any suits against them from the state to the federal courts. It was quite early held that a corporation could nevertheless remove a proper case, on the ground that the state law could not thus restrict federal jurisdiction. Insurance Co. v. Morse, 20 Wall. 445 (U. S. 1874). However, it was also held that a corporation which thus broke its agreement not to resort to the federal courts when sued in the state courts, could be punished by the state by having its right to do business revoked. Doyle v. Continental Ins. Co., 94 U. S. 535 (1876). This rather anomalous situation persisted through a long series of cases, but with a tendency to reduce the right of the states thus to prevent removals to the federal courts. Finally, in Terral v. Burke Construction Co., 257 U. S. 529 (1922), the principle was definitely laid down that a foreign corporation may remove a case to a federal court without liability to the penalty of being ejected from the state. The theory of the Court is that such a provision restricting the right of renoval is an unconstitutional limitation and is wholly void, notwithstanding the very wide powers which the states possess to impose conditions upon foreign corporations desiring to do business within their boundaries.

${ }^{*} 216$ U. S. 1 (1910).
} 
stock apportioned to the taxing state. ${ }^{13}$ Where a maximum tax liability is provided for, the case is not usually difficult; but even when no maximum is provided, the tax is not infrequently upheld. ${ }^{14}$ The difference is only one of degree, so far as interstate commerce is concerned, for if the corporation is engaged in interstate commerce, such a state tax may place a burden upon that commerce. ${ }^{15}$ The Court is compelled to admit this, but sustains the tax in this sort of case upon the ground that the burden is slight and is fair. It follows that a state may impose a tax which burdens interstate commerce, provided the Court feels that the burden is not unreasonably heavy; in other words, the basis is fundamentally economic rather than legal.

Somewhat more analogous to the precise problem of the burdening of federal instrumentalities are taxes upon the receipts from interstate commerce. Such taxes are clearly burdens upon interstate commerce, and yet are sustained to some extent. There is even one case, Maine v. Grand Trunk Ry., ${ }^{16}$ which holds that a state may tax the gross receipts of a foreign corporation engaged in interstate commerce. That case has, however, been substantially overruled, and it now seems to be the rule that the states may not tax gross receipts from interstate commerce, on the ground that this constitutes too great a burden upon that commerce. ${ }^{17}$

ws Western Cartridge Co. v. Emmerson, 281 U. S.' 511 (1930); Hump Hairpin Co. v. Emmerson, 258 U. S. 290 (1922); Kansas City, etc., Ry. v. Botkin, 240 U. S. 227 (1916) ; Kansas City, etc., R. R. v. Stiles, 242 U. S. 111 (1916). But the tax may no longer be based upon authorized, as distinguished from issucd, capital stock. Air-Way Electric Appliance Corp. v. Day, 266 U. S. 71 (1924).

14 Western Cartridge Co. v. Emmerson, supra note 13: Hump Hairpin Co. v. Emmerson, supra note 13; Kansas City, etc., R. R. v. Stiles, supra note 13.

${ }^{25}$ It is true that this sort of tax may alsa violate the due process clause of the Constitution because burdening property outside the taxing state, and this notwithstanding the fact that a maximum tax is provided for. Cudahy Packing Co. v. Hinkle, 278 U. S. 460 (1929). But there is a burden upon interstate commerce, irrespective of whether or not there is a maximum tax. Provision for a maximum tax limits, but does not remove, this burden.

142 U. S. 217 (1891).

"Crew Levick Co. v. Pennsylvania, 245 U. S. 292 (1917) ; Galveston, etc., Ry. v. Texas, supra note 5. See also New Jersey Telephone Ca. v. Tax Board, 280 U. S. 338 (1930). However, the states may tax gross receipts of corporations, including those received from interstate commerce, if the $\operatorname{tax}$ is in lieu of a property tax. United States Express Co. v. Minnesota, 223 U. S. 335 (1912). 
On the other hand, it has been decided in United States Glue Co. v. Oak Creck, ${ }^{18}$ that a state may impose a tax upon the net income of a domestic corporation, although nearly all that income was derived from interstate commerce. There can be no doubt that this is a burden upon such interstate commerce, but the Court holds that the burden is not so substantial as to warrant upsetting the tax, saying: ${ }^{19}$

"The difference in effect between a tax measured by gross receipts and one measured by net income, $* * *$ is manifest and substantial, and it affords a convenient and workable basis of distinction between a direct and immediate burden upon the business affected and a charge that is only indirect and incidental. A tax upon gross receipts affects each transaction in proportion to its magnitude and irrespective of whether it is profitable or otherwise. Conceivably it may be sufficient to make the difference between profit and loss, or to so diminish the profit as to impede or discourage the conduct of the commerce. A tax upon the net profits has not the same deterrent effect, since it does not arise at all unless a gain is shown over and above expenses and losses, and the tax cannot be heavy unless the profits are large. Such a tax, when imposed upon net incomes from whatever source arising, is but a method of distributing the cost of government, $* * *$ and if there be no discrimination against interstate commerce, $* * *$ it constitutes one of the ordinary and general burdens of government, from which persons and corporations otherwise subject to the jurisdiction of the States are not exempted by the Federal Constitution because they happen to be engaged in commerce among the States."

Similarly, in Peck \& Co. v. Lowe, ${ }^{20}$ it was held that the federal government, though forbidden by the Constitution to tax exports, might tax the net income of a corporation engaged exclusively in the exporting business.

It seems clear, therefore, that a tax upon the net income earned by interstate commerce is not an unconstitutional burden upon such commerce; and that even a tax measured by the stock of a corporation engaged in such commerce will be sustained if not

247 U. S. 321 (1918).

I Ibid. 328.

$=247$ U. S. 165 (1918). 
regarded by the Court as unduly burdensome. In other words, the test as to burdening interstate commerce is actually economic, and is so regarded by the Court. ${ }^{21}$

But these interstate commerce cases are not directly in point when the problem of state interference with federal functions is involved. Furthermore, the situation in the latter class of cases is so different as to make the interstate commerce cases largely inapplicable not only in form but in substance. In the interstate commerce cases the state is not taxing the federal government, or any function of that government; all that it is ever doing is burdening to a greater or less degree a function of national importance but carried on by private enterprise, which the federal government is given the power to regulate in order that it may be protected from stoppage or unreasonable burdening by the states. This is quite a different matter from a tax which falls upon the necessary functions of the federal government. It might well be ruled that a reasonable burden upon interstate commerce may be excused, but that the slightest burden upon a federal function-for example, the borrowing power-is invalid. ${ }^{22}$ There can be no doubt that any state tax measured by income which includes that from federal securities or based upon the assets of a taxpayer but not permitting the deduction from such assets of federal securities owned by the taxpayer, does affect to some degree the federal borrowing power, in that it falls indirectly but no less surely upon the federal securities. So, the question is whether any possible burden upon a federal function is sufficient to invalidate a state tax.

"n See the following language from Galveston, etc., Ry. v. Texas, supra note 5, at 227: "** * we are to look for a practical rather than a logical or philosophical distinction. The State must be allowed to tax the property and to tax it at its actual value as a going concern. On the other hand the State cannot tax the interstate business. The two necessities hardly admit of an absolute logical reconciliation * * *."

The difference is well pointed out by Mr. Justice Holmes, speaking for the Court, in Gillespie v. Oklahoma, 257 U. S. 501 (1922), where he said, at 505: “* * * The criterion of interference by the States with interstate commerce is one of degree. It is well understood that a certain amount of reaction upon and interference with such commerce cannot be avoided if the States are to exist and make laws * * *. The rule as to instrumentalities of the United States on the other hand is absolute in form and at least stricter in substance * * *." 


\section{Authorities Regarding Federal Securities AND OTHER FeDERAI, Functions}

It hardly needs to be said that a state tax which discriminates against federal functions is even more clearly invalid than one which discriminates against interstate commerce; ${ }^{23}$ but there is clearly no discrimination by the usual state tax, which applies to all securities, or the income from all securities, alike. But, on the other hand, it may well be doubted whether there can properly be said to be any tax burden upon federal securities unless there is a discrimination against them and in favor of state and private securities. Such a discrimination can exist only if the federal securities are taxed more heavily than other securities, since the only sensible reason for the rule that the states may not tax federal securities is to prevent the states from injuring the national borrowing power through the exercise of their own taxing power. If, as is usually the case, the tax is imposed at the same rate upon federal and all other securities, the federal borrowing power is not injured, since there is no inducement to prospective investors to refrain from purchasing federal securities because of the state tax. But, conceding the soundness of this position, it may still be argued that a slight additional burden is laid upon federal securities by any tax which diminishes the yield from such securities by a percentage of their value, even though a like tax is laid upon private securities. The basis for this argument is the low interest rate on federal securities-largely the result of the exceptional credit of the national government, and to the benefit of which it is entitled. A tax which diminishes this already low yield may be considered to bear more heavily upon the federal securities than one which diminishes to the same extent the higher yield of - other securities. But, at any rate, the actual difference, as reflected in market values, would probably be infinitesimal, and certainly would have no relation to a net income tax.

It is obvious, therefore, that any flat rule that the states may not impose a tax which in any degree affects federal instrumentalities means that there is an economic discrimination in favor of the federal government. Yet this discrimination is certainly

3 See California v. Central Pacific R. R., 127 U. S. 1 (1888). 
insisted on in some circumstances. One of the most conspicuous of these, and also one of the closest to the precise situation here under consideration, is the rule relating to the taxation of corporations having part of their capital invested in United States bonds. It seems to be settled that a state tax upon the capital of banks which have part of their capital invested in federal securities is invalid as constituting a burden upon such securities. ${ }^{24}$ That there is no real burden upon the securities by the tax is apparent, since the state is taxing the federal securities at no higher rate than it taxes private securities. Furthermore, as will presently appear, the Court does, or until recently did, permit some state taxes which are not different in economic effect from those here condemned. In a case where this want of a valid economic distinction between the taxes permitted and those condemned was pressed upon the Court, its only answer was that, "the question here is one of power and not of economics * * *." 25 If this is true, it is a question of sovereignty, and the economic test, which we have seen in the interstate commerce cases, has no application here.

No doubt the Court thought that this rule would benefit the federal government by enabling it to issue its bonds at a lower rate of interest on account of the tax-exempt feature. But this presupposes that there will be sufficient demand for federal bonds to enable the government to issue them at a rate of interest as much lower than the prevailing rates as the saving of taxes to the holders. That situation would mean that what each holder saves in taxes he would lose in interest, and the national government would get all the benefit. But in practice the bonds cannot generally be issued at so low an interest rate, and the difference goes to the holders rather than to the federal government. Besides, the fact that the national government is able to borrow below the prevailing rates of interest is probably due almost as much to its exceptional credit, which has just been referred to, as to any exemptions from state taxation which its securities may enjoy.

There are also decisions with respect to other federal functions which seem to take the same view that no state $\operatorname{tax}$ can be

* Bank Tax Case, 2 Wall. 200 (U. S. 1864) ; Bank of Commerce v. New York City, 2 Black 620 (U. S. 1862).

zome Savings Bank v. Des Moines, 205 U. S. 503, 519 (1907). 
laid which affects even slightly and indirectly any federal function. A conspicuous example is Dobbins v. Commissioners of Erie County, ${ }^{26}$ which holds that a federal officer cannot be taxed by a state upon his office, although all other persons holding a compensated office, whether state or private, are taxed at a similar rate. This was a direct though not a discriminatory tax; but the same rule is applied to an indirect tax in Telegraph $\mathrm{Co}$. v. Texas, ${ }^{27}$ and Williams v. Talladega. ${ }^{28}$ The first of these cases involved a state excise tax of one cent per message imposed upon a telegraph company; the other involved a license tax of one hundred dollars per year imposed upon the same company. Both taxes were held invalid because no deduction was made for United States government messages, on the ground that the tax was in effect on those messages and hence objectionable as a state tax on a federal activity.

Even more clearly in point is Indian Oil Co. v. Oklahoma, ${ }^{29}$ which holds that a domestic corporation cannot be taxed by the state of its organization, upon Indian oil leases held by it, nor can it be taxed upon the value of its stock computed by including the value of these leases. The Court took the position that the tax in either form was a burden upon the function of the federal government of protecting its Indian wards. This was an indirect and non-discriminatory tax, and the decision is therefore a perfect precedent for holding, as the Court recently has, ${ }^{30}$ that no state tax may be imposed which even indirectly affects federal securities.

But the strongeșt precedent of all for this result is Northwest-

${ }^{\infty} 16$ Pet. 435 (U. S. 1842). See also the converse case of The Collector v. Day, 11 Wall. 113 (U. S. 1870), holding that the federal government may not impose a tax upon the income of a state official. But see Wheeler Lumber, etc., Co. v. United States, 281 U. S. 572 (1930); Metcalf \& Eddy v. Mitchell, 269 U. S. 514 (1926).

27 105 U. S. 460 (1881).

$\approx 226$ U. S. 404 (1912). Other decisions to the same effect are Weston v. Charleston, 2 Pet. 449 (U. S. 1829) (holding invalid a city tax levied on -moneyed personal property because the ordinance did not permit the deduction of United States Bonds), and Federal Land Bank v. Crosland, 261 U. S. 374 (1923) (declaring unconstitutional a tax levied under state law for the recording of a Federal Land Bank mortgage, although recording was not compulsory, and all kinds of mortgages were subjected to a proportional $\operatorname{tax})$.

$\Rightarrow 240$ U. S. 522 (1916).

* Macallen Co. v. Massachusetts, 279 U. S. 620 (1929). See infra note 44. 
ern Ins. Co. v. IVisconsinn ${ }^{31}$ Here it was unanimously held that a state tax upon domestic insurance companies of three per cent of their annual gross receipts was invalid because the state would not permit the taxpayers to deduct from the gross receipts the interest from United States bonds held by them. The Court said : ${ }^{32}$

"Here the statute undertook to impose a charge of 3 per cent. upon every dollar of interest received by the Company from United States bonds. So much, in any event, the State took from these very receipts. This amounts, we think, to an imposition upon the bonds themselves and goes beyond the power of the State."

This case of course involved a tax upon gross receipts rather than upon net income; and a tax upon, or measured by, gross receipts is actually more burdensome than one with respect to net income, since the former tax must be paid although the business as a whole is unprofitable for the year. Of course the difference, so far as federal bonds are concerned, is not very important, since the amount of the tax in either case will be the same unless the business is conducted at a loss - an unusual situation in the case of financial institutions, which are the largest holders of these bonds. So the Northwestern case, standing alone, is enough to justify, and almost to compel; a decision that income from federal securities must be eliminated from taxable income where a state imposes an income tax upon the holders of the bonds.

But this is by no means the whole story. There are decisions by the Supreme Court of the United States which permit state taxation indirectly burdening federal functions or securities in circumstances where the burden seems to be just as real as in those cases just referred to where the tax was condemned by the same Court. To be sure, the Court has not admitted that it is permitting such indirect taxation, and has probably not always realized it; but the fact is that under some circumstances it is, or at least has been, allowed.

One of these classes of cases where the states are, or once were, permitted to impose an indirect tax burden upon federal securities, is where the securities are owned by domestic corporations, and the tax is regarded as merely upon the corporate fran-

275 U. S. 136 (1927).

s2 Ibid. 141. 
chise. It has already been pointed out that the states may not impose a direct tax upon the capital of a corporation which holds federal securities, since this means that the corporation is paying a larger tax by reason of its ownership of the federal securities. It has also been shown that the Supreme Court will not now permit states to impose "unconstitutional conditions" upon corporations, whether domestic or foreign. From these principles the invalidity of a franchise tax measured by the capital of a domestic corporation, such capital being invested partly in federal securities, seems clear. In this case, too, the tax is larger because of the ownership of federal securities, and in fact the situation is exactly the same from the standpoint of economics. Yet, under this exact state of facts, the franchise tax has been several times sustained. The leading case is Home Ins. Co. v. New York, ${ }^{33}$ but this was preceded by several other decisions to the same effect. $^{34}$ These cases were decided before the Court had worked out the doctrine with respect to "unconstitutional conditions," and so were largely based upon the supposed plenary power of a state over corporations; but they have never been explicitly overruled.

Another class of cases where an indirect tax upon federal securities is permitted is that involving taxes upon stockholders of corporations owning such securities. The leading case on the matter is Van Allen v. The Assessors. ${ }^{35}$ The tax is either measured by the value of the stock, which of course includes the federal securities held by the corporation, or else it is imposed upon dividends received by them from the corporations, such dividends presumably including the interest from the federal securities. The result is that the stockholders usually pay a larger tax than would be the case if the corporation did not hold these federal securities. Here again the situation resembles the one under consideration, although the tax on stockholders does not, of course, vary quite so directly with the amount of federal securities held by the corporation as does a tax imposed upon the corporation it-

134 U. S. 594 (1890).

at Society for Savings v. Coite, 6 Wall. 594 (U. S. 1867) ; Provident Institution v. Massachusetts, 6 Wall. 611 (U. S. 1867) ; Hamilton Co. v. Massachusetts, 6 Wa1l. 632 (U. S. 1867).

s 3 Wall. 573 (U. S. 1865). See also Cleveland Trust Co. v. Lander, 184 U. S. 111 (1902). 
self. The conclusion is irresistible that there is an indirect tax upon these securities, and furthermore there seems to be no method of upsetting such a tax (unless perhaps a palpably fraudulent tax for the purpose of burdening the federal government) even by the "unconstitutional condition" doctrine, at least as far as that doctrine has yet been carried. The Court was constrained to admit that this tax on stockholders does burden federal securities held by the corporation, when it held in Home Savings Bank v. Des Moines, ${ }^{36}$ that if the corporation itself was taxed, the value of the federal bonds must be deducted, although, as the Court conceded, the burden of this tax was precisely the same as one on the stockholders, where this deduction is not required. These cases of taxation of stockholders exemplify another situation where the doctrine of complete immunity of federal securities from the burden of, state taxation is not in fact fully adhered to.

Still other examples are the inheritance tax cases. Not only may the states tax bequests to the federal government, ${ }^{37}$ but it is also held that they may impose inheritance taxes upon the transfer by death, of federal securities. ${ }^{38}$ From an economic standpoint this is a tax upon the bonds, since they would, or at least ought to, sell at a higher price if immune from the tax. To be sure, this burden upon the federal borrowing power is not a serious one, and is perfectly fair, since state and private securities bear a like burden; but the same can be said of the state taxes invalidated in the cases above referred to. ${ }^{39}$ The distinction which the Court draws is that the inheritance tax is not on the bonds themselves but on their transfer by death, which is a matter solely within the control of the states. But it needs no argument to show that this distinction is purely verbal and without practical significance. Legally the tax is not upon the bonds, but from

Suprá note 25.

st United States v. Perkins, 163 U. S. 625 (1896). So, the federal government may tax legacies to the states or their instrumentalities. Snyder $v$. Bettman, 190 U. S. 249 (1903).

Blodgett v. Silberman, 277 U. S. 1 (1928); Knowlton v. Moore, 178 U. S. 41 (1900) ; Plummer v. Coler, 178 U. S. 115 (1900). It is also held that the federal government may tax the transfer by inheritance, of municipal bonds. Greiner v. Lewellyn, 258 .U. S. 384 (1922).

Cases cited supra notes 24-30. 
a practical economic standpoint it is; so these inheritance tax decisions are enough to justify (though undoubtedly not to compel) the approval of non-discriminatory state income taxation, without requiring the deduction of income from federal securities.

One recent case is squarely in point, and, if followed, could not fail to lead to the result just suggested. This is Flint v. Stone Tracy $\mathrm{Co}{ }^{40}$ which holds that the federal government might, even before the Sixteenth Amendment of the Constitution, levy an excise tax upon corporations measured by their net income, and, what is more important for our present purpose, might include in the income upon which the tax is measured, the interest from state and municipal bonds held by the corporation. The reasoning was that since Congress had power to tax these corporations it could include in the measure of the tax property-viz, the state and municipal bonds-which it could not tax directly. The Court said as to this : ${ }^{41}$

"It is therefore well settled by the decisions of this court that when the sovereign authority has exercised the right to tax a legitimate subject of taxation as an exercise of a franchise or privilege, it is no objection that the measure of taxation is found in the income produced in part from property which of itself considered is non-taxable. Applying that doctrine to this case, the measure of taxation being the income of the corporation from all sources, as that is but the measure of a privilege tax within the lawful authority of Congress to impose, it is no valid objection that this measure includes, in part at least, property which as such could not be directly taxed ***."

In this divided state of the authorities-notwithstanding the fact that these authorities are all decisions of the same Court-it would have been difficult for the most careful person to have ventured an opinion on the question as to whether a state which levies a tax upon corporate income, or measured by corporate assets, must permit the deduction of the income from federal securities, or the elimination of these securities themselves from the assets of the corporation, with respect to which the tax is

220 U. S. 107 (1911).

4. Ibid. 165 . 
measured. If Flint v. Stone Tracy Co., ${ }^{42}$ was to be accepted, it would seem clear that the states were under no necessity to make such a concession, for it was there held that the federal government need not scruple to impose such an indirect burden upon the states. Yet there was a line of cases of which Northwestern Ins. Co. v. Wisconsin, ${ }^{43}$ was the culmination, which looked in the other direction. However, in 1929 the question was definitely settled by the Supreme Court. Macallen Co. v. Massachusetts, ${ }^{44}$ was the case which effected this legal revolution.

\section{The Macalien Case 45}

This case arose as follows: Massachusetts has for some years imposed upon all domestic corporations a tax upon their net incomes derived from business carried on within the Commonwealth. ${ }^{46}$ Previous to 1925, interest from United States bonds could be deducted in computing taxable income, but by an amendment to the tax law in that year this deduction was no longer permitted. The Macallen Co., a Massachusetts corporation, was the holder of substantial amounts of United States Liberty Bonds and Federal Farm Loan Bands, both of which are by the terms of the federal statutes under which they were issued made expressly exempt from all state taxation (except inheritance taxes). ${ }^{47}$ The company, having been compelled to include the income from these bonds in its income subject to state taxation, in pursuance of the 1925 amendment mentioned above, brought suit in the state court for the abatement of so much of the tax as was attributable to this bond interest, claiming that the state tax was to this extent an infringement upon federal functions. This contention was not accepted by the Supreme Judicial Court of

Supra note 40.

- Supra note 31.

4t 279 U. S. 620 (1929). It may be noted that in its opinion the Court took the position that this question had never been in the least unsettled; that its own rulings on the point had always been entirely uniform. Enough has been said here to show that this astounding declaration is not to be taken seriously.

${ }^{45}$ See Powell, The Macallen Case-and Bcfore (1930) 8 NAT. Income TaX Mag. 47; Powell, The Macallen Case-and Beyond (1930) 8 Nar. INCOME TAX MAG. 91.

Mass. Gen. Laws (1921) c. 63.

" See Smith v. Kansas City Title \& Trust Co., 255 U. S. 180 (1921). 
Massachusetts, ${ }^{48}$ the court denying any relief to the company. Upon appeal to the Supreme Court of the United States, the decision was reversed; ${ }^{49}$ and it was adjudged that the petitioner was not liable to pay this part of the tax, upon the ground that it constituted a tax upon the interest from the Liberty and Farm Loan Bonds, which is, of course, forbidden.

The opinion of the majority, written by Mr. Justice Sutherland, takes the position that such a tax directly burdens the federal borrowing power, and is in contravention of the immunity from state taxation provided for in the statutes under which the bonds were issued. And the fact that the tax was inconsequential in amount was held to be immaterial, the Court stating and relying on Chief Justice Marshall's famous (but rather dubious) aphorism in $M^{\prime} C$ ulloch v. Maryland," that "the power to tax involves the power to destroy." It is admitted that the states have porver to impose franchise taxes upon their own corporations, but it is insisted that federal instrumentalities cannot be thus taxed, even indirectly. The opinion relies upon the amendment to the Massachusetts statute in 1925 as disclosing an intention by the legislature to impose a tax by indirection upon the interest from these federal securities, and does not find any excuse for this fraudulent intent in the alleged purpose to remove a discrimination against national banks.

Mr. Justice Stone submitted a dissenting opinion, in which Justices Holmes and Brandeis concurred; the Court thus dividing six to three rather than five to four, as was until recently very

Macallen Co. v. Commonwealth, 264 Mass. 396, 163 N. E. 75 (1928). It should be noted that the Massachusetts court relied especially on Provident Institution v. Massachusetts, supra note 34, and Hamilton Co. v. Massachusetts, supra note 34, in both of which the Federal Supreme Court had upheld Massachusetts taxation which seemed at least as burdensome to federal securities as the one then under consideration.

- Macallen Co. v. Massachusetts, sutpra note 44.

so Supra note 3, at 431. That the intrinsic soundness of this statement is extremely questionable must be evident from the principle that taxation is for the purpose of raising revenue, and accordingly that a tax designed to make impossible the thing purporting to be taxed is hardly to be considered as really a tax at all. It must be conceded that the Court did long and regularly sustain prohibitive taxes. United States v. Doremus, 249 U. S. 86 (1919); McCray v. United States, 195 U. S. 27 (1904). But such decisions as Child Labor Tax Case, 259 U. S. 20 (1922), show that the Court has abandoned this rather untenable theory. 
usual in this sort of case. The dissenting opinion cited the same decisions of the Supreme Court that had been relied on by the Massachusetts court, as sanctioning state taxation which appeared to bear at least as heavily upon the federal government as the one in question. Mr. Justice Stone takes the position that the taxing power of either state or nation is almost certain to have some indirect effect upon the other, and that such an effect should not invalidate its exercise unless the tax is not merely direct but also unduly burdensome; in other words, he believes that the test is practical rather than theoretical, and that by this standard the Massachusetts tax did not offend.

In appraising the majority opinion, the theory of the Court that the change in the Massachusetts tax law in 1925 showed a dishonest purpose of the legislature to subject federal bonds to. state taxation, may properly be first considered. ${ }^{51}$ The theory is that the state legislature had devised this fraudulent method of actually taxing the United States Bonds, which it understood that it could not tax directly, and was not in fact taxing prior to that year.

Obviously, the primary consideration is as to the basic soundness of the theory. Is it really a wicked and reprehensible act for a state to change its law so as to impose as heavy a tax burden upon federal securities (or indeed any other property) as it legally may? The question answers itself. It is simple nonsense to say that there is anything improper in the mere purpose of an individual or a state to exercise its legal rights to the very limit. The whole idea is therefore unsound.

But, conceding its soundness, it is not applicable here. It is submitted that the Massachusetts court in its opinion gave an adequate explanation to vindicate at least the good faith of the legislature. The state court pointed out that the legislature, having considered a number of previous decisions of the Federal Su-

s1. A good example of the application of this theory is Miller v. Milwaukee, 272 U. S. 713 (1927), where the Court (Justices Brandeis and Stone dissenting) held invalid a state tax exacted from stockholders on dividends paid from corporate income which came in part from United States securities on which the corporation had not itself been taxed. The majority of the Court thought that the obvious intent of the state legislature was to collect a tax upon these bonds, which it realized could not be taxed directly. See also National Life Ins. Co. v. United States, 277 U. S. 508 (1928), for another application of the same theory. 
preme Court (several of them coming from Massachusetts) which seemed to justify more burdensome taxes than the one proposed, ${ }^{52}$ realized that by permitting the deduction of the income from federal securities it was giving an economic bonus to corporations which had invested in federal securities, and thus indirectly to the federal government. This bonus, it thought it was entitled to withdraw, as it did by the amendment. The Massachusetts court also stated that it agreed with the interpretation of these cases under which the legislature acted. It has been shown here that, conceding that these cases are still to be recognized as authorities (and the Supreme Court has not even yet explicitly overruled them), this interpretation of them is correct; and they justify such a tax as Massachusetts imposed. Furthermore, it is pointed out that the state legislature was seeking to remedy an apparent discrimination against national banks, forbidden by a federal statute. ${ }^{53}$ Whether or not the remedy was effective, the very attempt would seem to prove the bona fides of the legislature.

If this point is to be taken seriously, it might indicate that some other state, the law of which originally provided for this sort of tax, might be able to sustain it. But this suggestion is of no weight. The Court obviously meant to invalidate the tax anyway, and this clearly unsound theory of legislative fraud is put in merely as a makeweight. Furthermore, to have a situation where some states could impose this sort of tax and others could not, would obviously be as absurd as it would be unjust. Whether the state acts fraudulently (as the Court defines fraud in this connection) or in the best of faith, it simply cannot, according to the Macallen case, impose a tax upon corporations without excluding from the measure of the tax federal securities held by the corporations or the fruit of such securities.

The result is that the Court has definitely gone the whole way in the direction indicated by such cases as Northwestern Ins. Co. v. Wisconsin, ${ }^{54}$ and just as definitely repudiated the doctrine of Flint v. Stone Tracy Co., ${ }^{55}$ and Home Ins. Co. v. New York. ${ }^{58}$

\footnotetext{
See supra note 48 .

* U. S. Rev. Stat. (1878) §5219, 12 U. S. C. A. (1927) § 548, which will be considered hereafter.

s Supra note 31 .

su Supra note 40.

* Supra note 33.
} 
As for the Flint case, it must be remembered that state securities are as immune from federal taxation as are securities issued by the national government from state taxation. The Flint case is therefore a direct converse of Macallen Co. v. Massachusetts, and the two cases are in conflict. The older case must accordingly be considered to be overruled on this point. It cannot be supposed that the Court means to permit the federal government to do to state securities the very thing which it will not permit the states to do with respect to federal securities.

Yet the Flint case is cited in the Macallen case, and not explicitly overruled. The same is true of Home Ins. Co. v. New York, and the cases following the same doctrine, which have already been referred to. ${ }^{57}$ Yet these cases can hardly stand with the new doctrine. There is no distinction as to the directness of the tax burden. There is a distinction in that in the Macallen case the tax was only upon net income and so might not have been due when it would have been in these previous cases. But this difference is one which tells against the older cases. If a tax upon net income is improper, a fortiori a tax, otherwise similar, which must be paid in years of loss as well, would be condemned. It would seem fairly clear, therefore, that these previous cases must be regarded as no longer representing the view of the Court.

The Macallen case thus represents a rather definite change of view by the Court, although this change was very clearly foreshadowed by the Northwestern case. Until recently the Court seemed disposed to limit its doctrine of immunity of federal securities from state taxation under some circumstances-although adhering to it in other circumstances. This means that there was no complete immunity-otherwise than in language. It does not seem possible to reconcile all the decisions previous to the Northwestern case, but the situation seemed to approach a distinction based on economic grounds. The Court apparently sustained indirect state taxation of federal securities whenever it considered that the burden was fair and not unreasonably heavy. As has been shown, mere freedom from discrimination has not always been sufficient-as it seems that it might well have been-to save the state tax; but the doctrinal immunity has not been adhered to when the Court considered it to work badly in a particular case.

or See supra note 34 . 
Taxation is an eminently practical matter, and so a practical rather than a doctrinal test seems desirable. But the Court now seems to be committed to the doctrinal test so far as state taxation of federal securities is concerned. Not only was the doctrine of complete immunity laid down as the basis of decision in the Macallen case (this has often been done before), but the majority of the Court declined to consider the practical aspects of the situation, as indeed the dissenting justices urged should have been done. Had the question been considered from a practical standpoint it seems probable that a different result would have been reached, since the burden upon the federal borrowing power from a tax like this one in Massachusetts seems quite unsubstantial.

\section{The Attempt to Withdraw Discrimination With RESPECT TO NATIONAL, Banks}

In the Macallen case, both the state court and the dissenting justices in the Federal Supreme Court sought to sustain the state tax on the ground, among others already considered, that the state was seeking to do away with a discrimination against national banks. This consideration has a very important relation not merely to the bona fides of the legislature but also to the practical results of the new doctrine, since federal bonds, bearing as they do low rates of interest, are not held to any great extent by ordinary business corporations but almost entirely by banks and other financial institutions. These financial institutions will therefore be the only corporations substantially benefited by the decision.

However, the problem of discrimination against national banks still presents itself, since the scheme which Massachusetts devised to avoid this discrimination has been invalidated; and this presumably means that all similar devices of other states will likewise not stand. It is now settled that national banks and their stock may not be taxed at all by the states except as permitted by Congress. ${ }^{58}$ The only permission which is accorded is that set forth by section 5219 of the Revised Statutes. ${ }^{50}$ This statute has always permitted, and still permits, the taxation by the states of the real estate of the banks; but until 1923 permitted no other

s Bank of California v. Richardson, 248 U. S. 476 (1919).

- Supra note 53. 
taxes to be imposed upon a bank itself, except with its own consent. $^{60}$ Until the same year the only tax which could be imposed upon the stockholders was one upon their stock. But the section was then wholly recast; and in accordance with that revision, together with a further amendment in 1926, the present situation is that any of the following items may be taxed: (1) the shares of stock; (2) dividends, by including them in the taxable income of the stockholders; (3) the net income of the bank; or (4) according to, or measured by, the net income of the bank. In cases (1) and (2) the tax is imposed upon the stockholders; in the other cases it is imposed upon the bank.

The new options are available only to states which provide for a tax upon the income of corporations or individuals, or both. Perhaps because of this reason, and also possibly because of the comparatively short period which has elapsed since the enactment of the statute in its new form, there are no adjudications with respect to any method of state taxation except the tax upon stock. Furthermore, the new provisions are somewhat complicated, and their meaning is perhaps not wholly clear.

Two general principles stand out in the present statute. The first of these is that only one of these forms of taxation may be used, except that a state which imposes a tax upon corporations and also includes dividends from corporations so taxed in the taxable income of individuals (thus imposing what is from the economic standpoint a double tax upon corporate earnings), may do the same with respect to national banks and their dividends. The second principle, which has always been controlling, is that there is to be no discrimination against national banks or their stockholders. In other words, a national bank may be taxed by the state where it is situated, but the tax must be no higher than if the bank were an ordinary business corporation; its stockholders may also be taxed (though not if the bank itself is taxed. except in the single case mentioned above), but their tax liability, whether as a property tax upon their stock or as an income tax upon the dividends received by them, must be no higher than if the stock which they hold were that of a business corporation rather than of a national bank.

This protection of national banks and their stockholders from

- Clement Nat. Bank v. Vermont, 231 U. S. 120 (1913). 
discrimination has always been a controlling feature of the statute, so that former adjudications under it are helpful in this connection, notwithstanding their limited scope. The rule laid down has been that the tax upon national bank stock nuust not be at a higher rate than that laid upon other moneyed capital in competition with national banks. ${ }^{61}$ The scope of the definition of capital in competition with national banks is by no means confined to that of state and private banks; it may even include capital of private investors if such capital is used extensively in such functions as are customarily performed by national banks. It is, of course. unnecessary that there be competition as to all functions of national banks; it is sufficient that there be substantial competition as to any part of the customary business of such banks. In this connection the recent expansion of the powers of national banks must be borne in mind. ${ }^{62}$

The tendency has been, therefore, to give wide scope to the protection of national banks against state taxation which might be construed to bear unfairly upon them or upon their stockholders as compared with corporations or individuals engaged in similar activities but not acting under a federal charter. It can readily be seen, however, that the holding of federal securities may result in a discrimination between a national bank and its stockholders as compared with its competitors, unless the taxability or freedom from taxation of the federal securities is the same on both sides.

Three decisions of the Supreme Court, though relating only to taxation of national bank stock, have a certain bearing on this matter. The first of these is Bank of California v. Richardson. ${ }^{63}$ Here a national bank was the owner of stock of a state bank and also of stock of another national bank. It was subjected to state taxation upon the stock of both banks held by it, and its stockholders were taxed upon its stock at a valuation including these other bank stocks. The Court held that the national bank

a First Nat. Bank v. Anderson, 269 U. S. 341 (1926) ; Merchants' Nat. Bank v. Richmond, 256 U. S. 635 (1921).

${ }^{62}$ First Nat. Bank v. Hartford, 273 U. S. 548 (1927) ; Minnesota v. First Nat. Bank, 273 U. S. 561 (1927). But the Court does not insist on equality of tax burden unless the competition is actually substantial. Georgetown Nat. Bank v. McFarland, 273 U. S. 568 (1927).

- Supra note 58. 
could not be taxed upon the stock of the state bank held by it (section $\mathbf{5 2 1 9}$ of the federal statutes then permitting no state tax upon national banks as such) but that its stockholders were properly taxed upon a valuation of its stock which included the state bank stock owned by it. It was also held that the national bank was rightly taxed upon the stock of the other national bank held by it, not because it (the bank which held the stock) was itself a national bank, but because it was a stockholder in a national lank, and section 5219 permitted it to be taxed as such. Thus far there was no particular difficulty, and the Court was unanimous. But the decision on the next point evoked a vigorous dissent. This was that the shares of the national bank whose stock was held by the other could not be considered in computing the value, for purposes of state taxation, of stock of the holding national bank in the hands of its stockholders. The only reason given was that such a tax would subject these stockholders to a greater liability than that contemplated by section 5219 . But it is clear that this marks a departure from the stock-of-stockholders rule; ${ }^{64}$ these stockholders were not the owners of the stock of the national bank owned by the bank whose stock they did own; yet they were given the benefit of it as tax-exempt.

The next decision is Des Moines Nat. Bank v. Fairweather. ${ }^{65}$ Here it was held that shares of national banks might be taxed to the stockholders without deducting tax-exempt securities held by the banks, although these securities were deducted from the taxable capital of other bankers. The explanation given was that the case of the national bank stockholders fell within the familiar stock-of-stockholders rule; that is, that they were not the owners of these tax-exempt securities, and were not entitled to any reduction of their tax liability on account of them. The Court admitted that this seemed to result in a discrimination against these national bank stockholders as respects private bankers and investors, but declined to change the rules with respect to tax-exempt securities on this account. Here we have a return to the stock-of-stockholders rule even though it seemed to result in discrimination against stockholders of national banks.

The final decision in this matter is Montana Nat. Bank v. Yel-

* See cases cited supra note 24.

os 263 U. S. 103 (1923). 
lowstone County." The situation in this case was much the same as in Des Moines Nat. Bank v. Fairacather. But here the stock of the state banks in the hands of stockholders was not taxed by the state, because of the ownership by the banks of federal securities. Thus the stockholders of the state banks benefited by the ownership by their banks of federal securities, whereas national bank stockholders were deprived of the benefit of the federal securities owned by their banks. This, the Court held, constituted a discrimination against the national bank stockholders and in favor of the stockholders in state banks. ${ }^{67}$ This discrimination could readily be avoided by taxing the stockholders of the state banks on the full value of their stock without deduction of the value of the federal securities owned by the banks, in the same manner as national bank stockholders were taxed. The case thus approves the stock-of-stockholders rule, but holds that it must be applied to all stockholders of corporations competing with national banks, in order to avoid a violation of section 5219 .

The result of these cases is that there need be no reduction from state taxation on the stock of national banks in the hands of their stockholders because of tax-exempt securities owned by the banks. Discrimination as against the stockholders of national banks must be avoided as respects the stockholders of other banks and financial institutions, by forbidding any corresponding tax reduction to them, but it need not be avoided so far as individual owners of such securities (whether bankers or investors) are concerned. The Court shows, however, a strong determination to limit any discrimination against national banks and their stockholders as closely as possible. Likewise, if the tax is imposed on dividends from national banks as a part of the net income of stockholders of the banks; it would be wholly impracticable to segregate the part of such income coming from federal securities held by a national bank (or for that matter any other dividendpaying corporation), and the states will undoubtedly be permitted

276 U. S. 499 (1928).

"This discrimination did not exist in Des Moines Nat. Bank v. Fairweather, supra note 65 . There, no tax reduction was accorded to stockholders of state banks on account of the ownership by their banks of federal ses curities. The only discrimination was with respect to private bankers ane investors. 
to tax such dividends without regard to the federal securities held by the banking corporation.

It would seem from the Macallen case that if the state tax is upon the net income of national banks, the banks would be permitted to exclude from their taxable income that part attributable to interest on federal bonds. But section 5219 seems to provide the contrary by saying that a state may in levying a tax according to or measured by the income of national banks "include the entire net income received from all sources," which clearly includes the income from federal securities. The question remains whether the new doctrine affects this provision.

It would seem upon principle that Congress has the power to subject such securities to the taxing power of the states. It is true that it was held in Choate v. Trapp, ${ }^{68}$ that such a withdrawal of an exemption from state taxation previously given by federal statutes may constitute a violation of the Fifth Amendment of the Constitution. But in that case the exemption was explicitly provided for; and in view of the settled principle that tax exemptions are to be strictly construed, ${ }^{69}$ it maybe doubtful how far the principle of the case applies to an exemption which is merely the result of decisions of the Court. This is especially so in view of the fact that at the time the securities involved in the Macallen case were issued, the law was, or was supposed to be, that such securities were in substance generally subject to state taxation, by treating the tax as not imposed upon the securities or the income from them but rather as upon the franchise of the corporation holding them. ${ }^{70}$

But there is a serious difficulty in this argument. The Court held in the Macallen case that an attempt by Massachusetts to subject domestic corporations to taxation upon income from state and municipal bonds issued as tax-exempt, was a violation of the contracts clause of the Federal Constitution. Much the same argument which has been made here against the application of Choate v. Trapp could have been made against the application of the contracts clause to the state bonds. It would seem from this

* 224 U. S. 665 (1912).

- This principle was fully recognized in Choate v. Trapp, ibid.

${ }^{20}$ See cases cited supra notes $33,34$. 
that the Court would be prepared to hold that an attempt by Congress to subject federal securities held by national banks to state taxation, however indirect, would fall within the prohibition of the rule of Choate v. Trapp.

But even assuming that Congress could have subjected these securities to state taxation, the question still remains whether section 5219 should be interpreted to be effective under the changed conditions resulting from the new holding. In subjecting the income from federal securities held by national banks to state taxation, Congress undoubtedly assumed that such income was subject to taxation in the hands of most competitors of these banks, ${ }^{71}$ so that the purpose was merely to remove any handicap in favor of national banks and so put them on an equal footing with their competitors. Now the Court has relieved competitors of national banks from this burden, so that if the income from federal securities held by these banks is still subject to state taxation they will be put at a distinct disadvantage as respects their competitors. This is contrary to the well defined policy of Congress in the past, as interpreted by the Court in connection with section 5219.72 It does not seem that the recent amendments evidence any' change of policy in this respect. It might be very serious for the federal government thus to handicap national banks, which were formed primarily as agencies for marketing governmental securities and which still perform this function to a considerable extent. To hold that the income from federal securities owned by national banks is subject to state taxation while that from similar securities owned by state banks is immune from such taxes, would discourage the investment by national banks in government. bonds. It is believed, therefore, that the Court is likely to hold that national banks have the same immunity from state taxation measured by the income from federal securities as do all other holders of these securities.

" Of course there might be discrimination against national banks, even under the doctrine of these older cases, when these federal securities are held by private individuals, and it is evident that Congress intended to subject them to this much discrimination. But in fact this discrimination is not very serious, since the great bulk of federal bonds are held by financial institutions which, if not national banks, are subject to taxation as corporations under the state laws.

"See cases cited supra notes 61-66. 


\section{Concl,usron}

It must be concluded that the present position of the Court marks a departure from, or at least a serious limitation of, the basic theory of many of its previous decisions with respect to state encroachments on federal functions through taxation. Hitherto, such encroachments have often been sustained, not merely with respect to interstate commerce, but even as to state taxes which affect federal securities, unless the taxes are direct, or unless the Court has considered that the burden thus imposed is unreasonable or is discriminatory. As has been pointed out, the Court has rarely used exactly this sort of language, and perhaps it has not realized that it was drawing this sort of line. But the net result of most of the decisions seems to be as just stated.

The new doctrine has no effect on the interstate commerce decisions, since in them the question is merely to what extent the states may regulate a business not carried on by the federal government but merely subject to its supervision in order that it may not be unduly burdened by the states. The power of the states to impose what the Court decides are not unreasonable burdens on interstate commerce will not therefore be affected. .

Even as respects state taxation affecting federal securities, the inheritance tax decisions will also probably stand, since the theory of the Court is that the tax is not levied upon the bonds themselves; and this notwithstanding the fact that the economic burden upon the bonds is as real, though not usually as heavy, as it is in the situation here considered at length. The same is true as the stock-of-stockholders cases; they have not been affected by the new ruling.

But by the recent decisions, ${ }^{73}$ the states are informed that federal securities, though they may be taxed non-discriminatorily through inheritance taxes, are exempt from any possible income or property tax burden, although this latter is also a non-discriminatory tax, and although the burden upon the federal borrowing power is more theoretical than real, at least from an economic standpoint. The only possible exception to the rigid rule is with respect to such of these securities as are held by national banks,

\footnotetext{
${ }^{7 a}$ Especially Northwestern Ins. Co. v. Wisconsin, supra note 31, and Macallen Co. v. Massachusetts, supra note 44.
} 
and even this, as we have seen, is doubtful. In other words, considering the matter as one of dollars and cents, which is the only justifiable way to consider such a practical matter as taxation, ${ }^{74}$ the states are compelled, not merely to refrain from discriminating against the federal government, but rather to discriminate in its favor. The rule of such cases as Home Ins. Co. v. New York, ${ }^{75}$ was illogical, but it was entitled to commendation as an exception to the unfortunate rule that a tax upon, or measured by, corporation capital must be diminished in proportion to the amount of such capital invested in federal securities. Now the exception is given up, and the rule is not only adhered to in all situations but is extended to apply to taxes upon corporate income.

The change seems unfortunate, not only as unduly burdening the taxing powers of the states, but as affording little substantial benefit to the federal government. It will not greatly help the nation, since purchasers of its securities will generally be able to force a higher rate of interest than is commensurate with the benefit of freedom from state taxation. Thus the real beneficiaries of the new rule will be the holders of these securities-for the most part, banks and other financial institutions.

On the other hand, the states have one advantage, if, as seems inevitable, Flint v. Stone Tracy $\mathrm{Co}^{7{ }^{76}}$ is overruled on this point. It would seem that interest from state securities is now necessarily exempt from federal income tax. ${ }^{7 \tau}$ This will, of course, be of some benefit to the states-at least it should benefit them as much as the rule of the Macallen case can benefit the federal government.

" See the language quoted from Galveston, etc., Ry. v. Texas, supra note 21. While this was an interstate commerce case, the same rule seems to be applied in the cases cited supra notes 33,34 , where the state tax included federal securities in its measure.

${ }^{73}$ Supra note 33.

"Supra note 40.

" At present the federal government does not attempt to impose a tax upon corporate income including that from state bonds. But it seems that such a tax, if ever again attempted, will be invalidated by the Court. Furthermore, it would seem that if any capital stock taxes are imposed in the future by the federal government, corporations subject thereto may exclude from the value of their stock upon which the tax is computed, the value of the securities issued by states, which are owned by them. Otherwise, the federal government would be permitted to levy an indirect tax upon state securities. 
But on the whole, the result of the new doctrine seems not to be commended. Considered by itself, it imposes a heavy burden upon the states without a corresponding benefit to the national government. And even though the Supreme Court does explicitly overrule Flint v. Stone Tracy Co., and thereby equalize the balance between state and nation, the states are confronted with the rather difficult task of adjusting their taxing systems, as respects national banks and otherwise, to accord with the new rule. That this problem is regarded by the states as a rather difficult one is shown by the fact that several states joined with Massachusetts in petitioning for a rehearing in the Macallen case-a petition which was denied by the Court at the opening of its next session. ${ }^{78}$ The rule of law laid down by the case must accordingly be taken to represent the settled view of the Court. ${ }^{79}$ It is only to be hoped that the Court will equalize the situation by according the same complete exemption from federal taxation to the securities issued by the states which it has already given to federal securities as respects state taxation. The new rule seems unwise; but it will be tolerable if it works both ways.

Robert C. Brown.

INDIANA UNIVERSTYY SChOOL, OF LAW.

“ Macallen Co. v. Masachusetts, 280 U. S. 513 (1929). Petitions for rehearing were also filed by the American Bankers Association and the Massachusetts National Bank Association.

: See also Missouri v. Gehner, 281 U. S. 313 (1930), holding invalid a state statute requiring each insurance company to pay a tax on the value of its assets in excess of required reserves and unpaid claims, and requiring such reserves and unpaid claims to be reduced by the proportion that the value of the government bonds held by the company bears to its total assets. The Court held that this was an indirect tax upon the government bonds. While the decision seems to be a logical result of the doctrine of Miller v. Milwaukee, supra note 51, yet it gives further evidence of the determination of the Court to relieve government bonds from all possible burden of state taxes, no matter how indirect or non-discriminatory. 